\title{
The Fetal Patient, Beyond Prenatal Diagnosis
}

\author{
Elia Lara Lona ${ }^{1 *}$, Ma de la Luz Bermúdez Rojas ${ }^{2}$ and Daniel Diaz Martínez ${ }^{2}$ \\ ${ }^{1}$ Department of Medicine and Nutrition, Mexico \\ ${ }^{2}$ Ministry of Health, State Center for Timely Screening, Mexico \\ *Corresponding author: Elia Lara Lona, Department of Medicine and Nutrition, University of Guanajuato, Mexico
}

\begin{tabular}{|c|c|}
\hline ARTICLE INFO & ABSTRACT \\
\hline 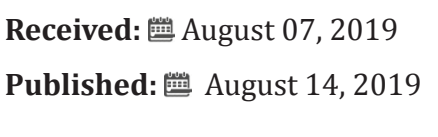 & $\begin{array}{l}\text { Citation: Elia Lara Lona, Ma de la Luz Bermúdez Rojas, Daniel Diaz Martínez. The Fe- } \\
\text { tal Patient, Beyond Prenatal Diagnosis. Biomed J Sci \& Tech Res 20(4)-2019. BJSTR. } \\
\text { MS.ID.003477. }\end{array}$ \\
\hline
\end{tabular}

\section{Mini Review}

Since the three technological innovations that make up the device for prenatal diagnosis (amniocentesis, genetic identification and ultrasound) [1,2], were developed and consolidated, the technology for therapeutic intervention has also developed exponentially, with consequences for the fetus and the pregnant woman who have undergone of multiple approaches to public health policy with social accounts of impact on maternity, kinship and general society [3-5].

The efforts of governments to make timely diagnoses that prevent premature death or disability are variable depending on priority and financial resources, but the commitment should not remain there, but to ensure care for the pathologies identified. Although it has been shown that strategies for the prevention and timely identification of pathologies in the perinatal period should be carried out from the first weeks of gestation and even from the preconception period, the data show that diagnoses have generally been made from the $2^{\text {nd }}$ and $3^{\text {rd }}$ trimester of pregnancy.

There are several causes that favor that the pregnant woman's first contact with the health system be delayed, basically due to the criteria of access to health services, organizational barriers in establishments, quality of care and processes socio-cultural and ideological issues

In the state of Guanajuato in Mexico, located in the center of the country, a comprehensive strategy for the timely identification of pathologies in the fetus and mother has been implemented following

the model proposed by [6] of the turn the pyramid of prevention and guaranteeing pharmacological treatment (progesterone), nonpharmacological (psychology, genetic counseling, nutrition) and surgical (fetal surgery or cerclage) as appropriate. The strategy includes the identification of risks for both the fetus and the mother in 4 main lines: birth defects, probability of presenting intrauterine growth retardation, pre-eclampsia and prematurity.

One of the most important aspects to highlight is the scheme of financing and assurance of care for the mother, the fetus and the follow-up until two years after birth, which has been possible with the model of the Social Protection System in Health, the resource of the state itself and with the support of civil society. Five years after its implementation, there have been amazing results with the attention of more than 26 thousand pregnant women.

\section{Reference}

1. Löwy I (2014) Prenatal diagnosis: The irresistible rise of the 'visible fetus'. Stud Hist Philos Biol Biomed Sci 47: 290-299.

2. Casper JM (1998) The making of the unborn patient: A social anatomy of fetal surgery. Rutgers University Press, pp.267.

3. Williams C (2005) Framing the fetus in medical work: Rituals and practices. Soc Sci Med 60: 2085-2095.

4. Morgan LM, Wilson Michaels M (2016) Fetal subjects, Feminist positions. University of Pennsylvania Press, pp.345.

5. Rothman KB (1989) Recreating Motherhood. Ideology and technology in patriarchal society. Norton, USA, pp. 282.

6. Nicolaides KH (2011) A model for a new pyramid of prenatal care based on the 11 to 13 weeks' assessment. Prenat Diagn 31: 3-6. 
ISSN: 2574-1241

DOI: 10.26717/BJSTR.2019.20.003477

Elia Lara Lona. Biomed J Sci \& Tech Res

(C) (P) This work is licensed under Creative Commons Attribution 4.0 License

Submission Link: https://biomedres.us/submit-manuscript.php

$\begin{array}{ll}\text { BIOMEDICAL } & \text { Assets of Publishing with us } \\ \text { RESEARCHES } & \text { - Global archiving of articles } \\ & \text { - Immediate, unrestricted online access } \\ & \text { - Rigorous Peer Review Process } \\ & \text { - Authors Retain Copyrights }\end{array}$

